\title{
LUT
}

University

\section{Elements of socially sustainable innovation processes in Finnish urban development}

Parjanen Satu, Hyypiä Mirva, Martikainen Suvi-Jonna, Hennala Lea

This is a Post-print version of a publication

published by John Wiley \& Sons

in Sustainable Development

DOI: $10.1002 / s d .1886$

Copyright of the original publication: (C) 2018 John Wiley \& Sons, Ltd and ERP Environment

Please cite the publication as follows:

Parjanen S, Hyypiä M, Martikainen S-J, Hennala L. Elements of socially sustainable innovation processes in Finnish urban development. Sustainable Development. 2018;1-8. https://doi. org/10.1002/sd.1886

This is a parallel published version of an original publication.

This version can differ from the original published article. 


\title{
Elements of socially sustainable innovation processes in Finnish urban development
}

\author{
Abstract \\ The purpose of this article is to study socially sustainable innovation processes in urban \\ development. Which elements can be identified to support socially sustainable innovation \\ processes in urban development and how were the elements realized in urban innovation \\ processes in Finland in 2013 and 2015 are the research questions. According to the literature \\ review, socially sustainable innovation processes include an open and interactive development \\ approach, resident and user-driven involvement, communication, learning and feedback, and \\ impact assessment. In order to track the elements in practice a qualitative approach using case- \\ based research was conducted. The results reveal that urban development processes in Finland \\ could not be considered socially sustainable because the elements are realized differently. \\ Though many current processes include resident participation, impact assessment is lacking. The \\ study also presents a strategy for how to create more socially sustainable urban innovation \\ processes.
}

Keywords: socially sustainable innovation process, sustainable development, resident participation, urban development 


\section{Introduction}

In recent years, social sustainability has gained increased recognition as an important component of sustainable development. It has begun to receive political and institutional endorsement on the sustainable development agenda and in the sustainable urban development discourse (Colantonio and Dixon, 2009). According to Mehdipour and Rashdi Nia (2013), the concept of urban development is essentially a process concentrating on all elements of an area that contribute not only to the creation of a more environmentally friendly city but also to the provision of social equality and economic growth, which altogether result in a more sustainable urban space. They consider an urban development approach as a response to the opportunities and challenges presented by social, economic, physical and environmental changes. Hence, this fact can be reflected in that urban development must be translated first and foremost into its trend toward sustainable development.

Social sustainability is broadly defined by Chiu $(2003,245)$ as "maintenance and improvement of the well-being of current and future generations." Others, such as Littig and Griessler (2005), suggest social sustainability means the satisfaction of basic human needs, the continual reproduction of humans and the subsequent continuation of culture. These definitions are inadequate in capturing the complexities of social sustainability. Social sustainability may extend further than the consideration of basic needs, culture, well-being and the reproduction of humanity. A more comprehensive definition of social sustainability with a special focus on urban environments is provided by Stren and Polèse (2000, 15-16). They emphasize the economic (development) and social (civil society, cultural diversity and social integration) dimensions of sustainability, highlighting the tensions and trade-offs between development and social 
disintegration intrinsic to the concept of sustainable development. However, they also acknowledge the importance of the physical environment within the urban sustainability debate. Their notion of social sustainability as "policies and institutions that have the overall effect of integrating diverse groups and cultural practices in a just and equitable fashion" (Stren and Polèse, 2000, 229) is highly relevant to cultivating socially sustainable innovation processes in urban development.

There is a need to develop an understanding about socially sustainable innovation processes in the context of urban development. The objective of this research is to locate connections between multifaceted concepts and practice. This paper seeks to identify the opportunities and obstacles to the socially sustainable innovation process in urban development in Finland. The novelty of the article is outlined by presenting a framework grounded in sustainable development, social sustainability, innovation and urban planning. Although the socially sustainable innovation processes have much in common with social innovations, etc., in socially sustainable innovation processes the emphasis is on the process of innovating rather than the end result. Thus, the emphasis is on how to organize the development process in genuinely participative and citizenoriented, or even citizen-led, ways. For that reason, the research questions are i) which elements can be identified to support socially sustainable innovation processes in urban development, and ii) how were the elements realized in urban innovation processes in Finland in 2013 and 2015. In addition, a strategy for including the elements of socially sustainable innovation processes more tightly in urban development is introduced. 


\section{Sustainable development}

Within the sustainability discourse, the definitions concerning sustainability are still multifold and competing depending on the context (Larsen, 2009). The triple-bottom line concept has gained popularity in the consideration of sustainability as a construct of ecological, economic and social pillars (see the Johannesburg declaration on Sustainable Development, 2002), and it has also become one of the main theories for the operationalization of sustainability (Peterson, 2016). More recently, the sustainability concept has been divided into more than three parts, and cultural and even spiritual pillars have been added in order to gain a more holistic approach to sustainability (Dessein et al., 2015).

Krueger and Buckingham (2012) have formulated a framework for urban sustainability that uses the sustainability tripartite and links sustainability in urban contexts to environmental concerns, social justice and economic prosperity (e.g., markets supporting sustainability goals). They note, however, that in practice these discussions can conflict with each other. The economic pillar can take over, and there were examples where "ideas and innovation $[\ldots]$ were captured by capitalist urban development" (ibid. 500). Since the late 1990s, sustainability has come to be the pervasive goal of urban planning (Yung et al., 2011). Because of the growing urban population, cities play vital roles in sustainable development (Dempsey et al., 2009). Human beings are the main focus in the definition of a sustainability concept, but less attention has been given to the definition of social sustainability in built environment disciplines (Dempsey et al., 2009).

\section{Social sustainability}


As multiple as the definitions of sustainability are, the definitions of social sustainability vary from the elaborate identification of the elements in social sustainability (see Vallance et al., 2011) to considering social sustainability as an issue of social nature which is inseparable from and interwoven with ecological and economic questions (Peterson, 2016). According to Sharifi and Murayama (2013), social equity, engaged governance, social interaction, interpersonal relations, social cohesion, attachment to a place, community stability, health and well-being, inclusion, and security are the major relevant criteria for social sustainability in urban contexts.

Bramley and Power (2009) introduce a conceptual framework for urban social sustainability. It includes two overarching typologies: social equity and sustainability of communities. The latter refers to social interaction through social networks in the community and pride, the sense of the place, safety and security. The sustainability of the community is defined as "the ability of society itself, or its manifestation as local community, to sustain and reproduce itself at an acceptable level of functioning" (Bramley and Power, 2009, 421). Bramley and Power (2009) argue that these typologies of social sustainability are reflective of two recognizable, overarching concepts situated in the literature. Social equity issues are described as "powerful political and policy concerns," and the centre upon a distributive notion of social justice. Issues of sustaining the community are seen as more unclear. This model positions the achievement of social sustainability as being about attaining harmony and eliminating discord. This position has synergies with the Brundtland Commission's "we can have it all" definition that underplays social, environmental and economic tensions in processes associated with sustainability. 


\section{Open innovation}

Open innovation has received increased attention over the past decade in development and innovation literature. Open innovation assumes that organizations should use external as well as internal ideas as they look to advance their innovations (Chesbrough, 2003; Chesbrough et al., 2006; von Hippel, 2005). The concept provides an important contribution to the understanding about the complex development processes in society, such as those of contemporary city development (Mattsson and Sørensen, 2015; Mieg, 2012). One aspect of open innovation is userdriven innovation. User involvement may generate valuable ideas, speed up the innovation process and support the diffusion of innovations (Alam, 2002; von Hippel, 2005).

Innovation research seems to be built on a fundamental assumption that innovation is always something good. Yet, the consequences of an innovation may be intended or unintended, and further still these intended or unintended consequences may be defined as desirable or undesirable. Certain stakeholders tend to more frequently influence the introduction of innovations while others are more often affected by them. These roles may also overlap to some degree; adopters may apply an innovation in unanticipated ways, thereby affecting it. Also, desirable and undesirable effects overlap and coincide; some adopters will find the innovation desirable, and features that some consumers love others may hate. (Sveiby et al., 2009.)

The synergetic relationship between sustainability and innovation at the core of organizations drives the development of different kinds of innovations and in doing so creates long-term social, environmental and economic value (Boons et al., 2013). Thus, sustainable innovation refers to sustainable innovation as an outcome, but also refers to innovation processes where sustainability 
aspects are taken into consideration. The sustainable innovation processes often differ from conventional innovation mainly in purpose and direction. Whereas innovation often is intended to advance business performance and motivate economic growth, sustainable innovation aims to achieve this improvement through the integration of economic, environmental and social concerns (Fortkamp and Staffas, 2012). The sustainable innovation process is a process where different kinds of sustainability considerations are integrated into organizational systems from idea generation to research and development and implementation. The socially sustainable innovation process could be defined as the ability of a community to innovate processes and structures, which not only meet the needs of its current members but also support the ability of future generations to maintain a healthy community.

\section{Urban planning}

Many scholars also highlight the role of participation as important criteria for social sustainability in urban planning (Spangenberg, 2004; Choguill, 2008; Dempsey et al., 2009). Public participation promotes the innovative process that guarantees the efficiency of sustainable urban planning and enhances a sustainable new way of living in a community (Amado et al., 2009). The sustainability of a community involves social interaction between community members; the relative stability of the community, both in terms of the overall maintenance of numbers/ balance and of the turnover of individual members; the existence of, and participation in, local collective institutions; formal and informal levels of trust across the community, including issues of security from threats; and a positive sense of identification with, and pride in, the community (Dempsey et al., 2009). 
Wood (2002) identifies two sets of reasons to support resident participation in urban planning. The first set comprises the managerial or pragmatic benefits of involving local people. The perceived managerial benefits derived from resident involvement include financial efficiency and effectiveness, such as the efficiency savings that might be derived from their inclusion. The second set consists of the notion that residents have a right to influence the decisions that affect them. This has been labelled the citizenship perspective. Across both of these perspectives lies the notion that participation improves social cohesion and leads to the development of more sustainable communities (Wood, 2002). Participation is a way to meet social sustainability. Regarding the fundamentals of sustainable development, not only is reconstruction not enough, but people's participation is also important. Sometimes pseudo-participation may result in public satisfaction, but it may not fully meet sustainable developmental goals in urban planning projects (Mahdavinejada and Amini, 2011).

To answer the first research question, Figure 1 introduces the elements which support socially sustainable innovation processes according to the literature. 


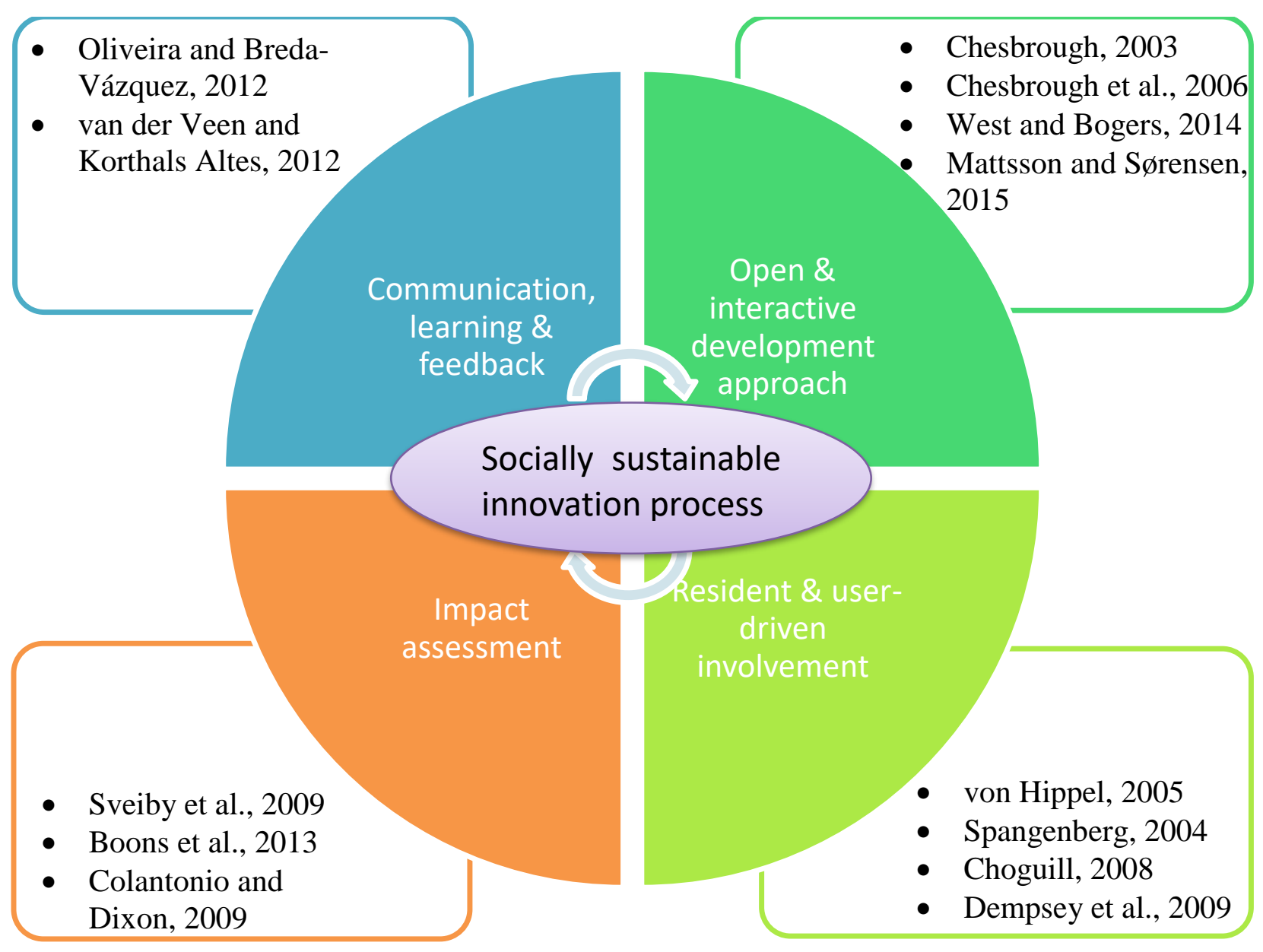

\section{Methodology}

\section{The background}

Finnish government housing policies strive to ensure that cities and residential areas in Finland will remain comfortable, safe and attractive places to live in. Introducing new activities and involving the residents in the process are the objectives when developing residential areas. Multiagency measures can prevent residential segregation, foster service provision and economic activity in residential areas, enhance residents' involvement, health and well-being, improve 
interaction between groups of residents, and create comfortable, safe and interesting living environments (ARA, 2013). In this research, the development contexts are in different urban areas in southern Finland. What these residential areas have in common is that they have all participated in development programs organized by The Housing Finance and Development Centre of Finland. The residential areas have been selected for the development program based on their socioeconomic indicators. In these areas, the average income is lower and the unemployment rate higher than in the rest of the areas of the city in question. In addition, these areas are at risk of residential segregation.

\section{Data collection}

The data collection was based on the theoretical literature review (Reuber, 2010) and semistructured interviews (Brinkmann and Kvale, 2014). The purpose of the literature review was to reveal what theories or research already exist, the relationships between them and to what degree the existing theories have been investigated. The main key words were sustainability, sustainable development and innovation. These were combined with concepts like urban planning, urban development and urban regeneration. The scientific databases, like EBSCO, SCOBUS and ABI, were used to conduct the review. The results were formulated thematically (Figure 1).

The suitability of semi-structured interviews for this study is related to the fact that it allows the acquiring of information about a topic which is less known or rarely studied, as in this case. The advantage of a semi-structured interview is also that a researcher can make additional questions and solve possible misunderstandings during the interview (Brinkmann and Kvale, 2014). The interviews were conducted by four researchers. The interview themes were formulated based on 
theoretical and observational evidence from the urban development processes. The themes of the interviews were urban development in different municipalities; the role of the residents in urban planning; communication; the development of residential areas; and the future of the development programs for residential areas.

Altogether 32 interviews were recorded, varying in time from one to one and a half hours. The research subjects were public authorities, residents, researchers and government officials. The job titles of the interviewees ranged from resident liaison officer, residents' house coordinator and project manager to residence director, urban planning manager, architect and development manager, to name a few examples. Most of the interviewees worked or have been working in the urban development projects financed by The Housing Finance and Development Centre of Finland. The aims of the ongoing projects included in this study have been introduced in Table 1. In addition, the interviewees made references to earlier projects. 
Table 1. Aims of the urban development projects.

\begin{tabular}{|l|l|}
\hline The main urban development projects \\
\hline Project 1 & $\begin{array}{l}\text { Strengthening participation by developing a new concept for a community house } \\
\text { Cross-sectoral collaboration (especially answering the challenges of the families } \\
\text { of small children) } \\
\text { Supporting social integrity by supplementary building } \\
\text { Building the community house } \\
\text { Repairing lighting, parks and playgrounds }\end{array}$ \\
\hline Project 2 & $\begin{array}{l}\text { Improving the comfortableness of the residential areas } \\
\text { Developing residents' participation possibilities } \\
\text { Reducing exclusion with new ways of doing and best practices } \\
\text { Repairing lighting and parks } \\
\text { Developing the network of the biking routes }\end{array}$ \\
\hline Project 3 & $\begin{array}{l}\text { Creating an integrated and functional concept for development } \\
\text { Creating new ways of using space } \\
\text { Strengthening the growth and social integrity of young people } \\
\text { Repairing lighting, parks and playgrounds (including using arts in making } \\
\text { environment more interesting) }\end{array}$ \\
\hline Project 4 & $\begin{array}{l}\text { Developing and piloting a new regional service model to answer the challenges of } \\
\text { young people } \\
\text { Developing cross-sectoral activities } \\
\text { Diversifying the dwelling stock } \\
\text { Developing the recreation area, fixing the gardens in tenement buildings and } \\
\text { building new spaces for resident activities }\end{array}$ \\
\hline Project 5 & $\begin{array}{l}\text { Developing a new kind of development model for the residential area } \\
\text { Supporting the community spirit } \\
\text { Supporting interaction between different resident groups } \\
\text { Repairing lighting, playgrounds, recreation areas, walkways and parks }\end{array}$ \\
\hline
\end{tabular}

The interview data was transliterated and the software ATLAS.ti was used to help analyze the data. Content analysis was carried out by coding the elements of socially sustainable innovation processes separately from each interview. In addition, opportunities and obstacles to the socially sustainable innovation processes were identified. To ensure reliability, the researchers analysed analyzed all the data independently and collectively. 


\section{Results}

\section{Resident and user-driven involvement}

In the 1980s, development projects focused mainly on the physical and economic renewal of degraded areas. However, since the 1990s this approach has been replaced by a more integrated approach to urban redevelopment across the European Union, which linked the stimulation of economic activity and environmental improvements with social and cultural elements (Colantonio and Dixon, 2009). The interviewees have also noticed the shift toward a more integrated approach. The shift to focusing on issues that are more human meant that the role of residents in urban innovation processes has become more obvious. The aim of participation was not only to listen to the inhabitants but "to get information" and implement it in development. The participation is not an end unto itself. It is essential "what we can get with participation," explains one interviewee.

Resident participation is easier nowadays because residents are more willing to develop their own areas and more aware about their right to be heard. Earlier it has been more "the persuasion of the residents, but nowadays people are on their toes to say what they want." There has also been a change in attitude among residents. They no longer expect the municipality to do everything. One interviewee was pleased: "The residents have realized that the municipality does not have endless amounts of money. They are ready to participate in voluntary work and they also suggest themselves what can be done on a voluntary basis." Yet, there are groups of people in resident participation who are more difficult to get involved in community house events or development work. It is challenging to reach these people and identify what kinds of activities would rope them in. Different participation methods do not necessarily guarantee participation, but e.g., art-based methods may draw some new people into various development activities. 
It is important that developers are present in areas where they work so that residents get to know them. The need for their presence was emphasized in the interviews and was considered as a way to build trust. Aspects such as being "faceless" and "the change of workers" were considered detrimental to participation. The importance of presence lies in the fact that social relations coordinate transactions and enable the exchange of knowledge (Boschma, 2005). According to the results of this study, it is important that those workers who are responsible for urban development do not frequently change. While the emphasis on the human-based participative approach has gained popularity, it has also raised concerns about the authenticity, appropriateness and quality of participative practices. Interviewees described that they had noticed that "in many places participation is at a training level, it feels that in many places resident participation is not genuine."

\section{Communication, learning and feedback}

Functioning communication was repeatedly mentioned as a substantial factor for the openness and transparency of the innovation processes. Communication is enhanced by using different channels and good relations with local media. "The bush telegraph" was mentioned in almost every interview as an important channel. Social media was also mentioned, but it did not necessarily reach older people. It was acknowledged that there is a need to develop more systematic ways to share knowledge and communicate with residents. For example, different concepts such as segregation and inclusion, or the language used by municipal officials, may cause misunderstandings between developers and residents. 
The role of communication in socially sustainable innovation processes was seen as a method of engaging inhabitants in development and building a more positive image of the place. Usually, places undergoing urban development projects have often acted as recipient areas for low-income newcomers to the city because of their affordable rents and lower cost of living. Thus, it is important to improve the image of these places in order to attract new inward investments in social, economic and green infrastructure, as well as middle-high income people to these neighborhoods (Colantonio and Dixon, 2009). However, incommunicable information is often also present in the urban innovation process. An adequate communication system may tackle doubt, lack of trust and other obstacles in the development and diffusion of innovation. This emphasizes that communication is a crucial factor in sustainability and innovation (Oliveira and Breda-Vázquez, 2012).

\section{Open and interactive development approach}

At the organizational level, the realization of the elements of socially sustainable innovation is dependent on the strategies of the urban areas. The interviewees considered it essential that the objects of urban development arise from the strategy of the city. According to one interviewee, the strategy of the city supports socially sustainable innovation because it "highlights the residentbased viewpoint." In another city, both interviewees considered their city strategy to be too ambiguous, and to them it was e.g., "difficult to know how to implement the strategy in practice." Unlike the traditional approaches of strategy making to set fixed goals, Bagheri and Hjorth (2007)

argue that triggering a social learning process with the involvement of all stakeholders and planners would be the most suitable strategy for sustainable development. 
The interviewees stressed the need to take advantage of regional success factors, such as a sense of community and the comfortableness of the environment. Urban social sustainability cannot be limited to a technical, problem-solving approach or institutional management. On the contrary, considering the local context and its history is fundamental to fostering a dynamic of sustainability (Hilgers, 2013). In many interviews, the poor economic situation was mentioned as the reason why the elements of socially sustainable innovation were not incorporated in urban development. One interviewee explained that local democracy is implemented well in a bigger city because "the resources are different when compared with this town." The lack of resources prevents using different virtual methods for participation or hiring more community workers, but it was not considered to just be a preventive factor. Perhaps it also makes more room for creative solutions. In the development "the functioning of the basic model" and "the continuum of development" were considered more essential factors. It was considered important to be able to utilize the results gained in previous projects. There is a danger of "the wheel being reinvented" in every project. Even if the strategy supports socially sustainable innovation, one problem is that "we always develop the same areas" and "we do not have the courage to make anything truly big," according to the interviewees for example, complex urban development projects may entail inclusionary goals. In order to recognize diversity, and as a response to many uncertainties, learning during their realization becomes an important issue (van der Veen and Korthals Altes, 2012).

Leadership in socially sustainable innovation is committing and taking responsibility: "Those people who decide about resources are in a key position and their contribution is essential." Nothing can be done only bottom-up. Committed leadership is also essential when we think about the effects the projects have. When a development project ends, there is a danger that the related 
activities also end. One reason for this is that projects are often dependent on one person, and new ways of doing things are not implemented.

One interviewee defined socially sustainable innovation in the context of urban development as "putting different actors together." The collaboration between heterogeneous actors would benefit socially sustainable innovation. However, the role of the private sector in urban development is still minor, and sometimes even the physical distance between departments in a municipality may hinder the collaboration. One interviewee explained that "we who work in the same building converse often, but the education department is across the street," and the connection to that department has been very small. This could mean that a problem is dealt only from one perspective despite being connected with many issues, meaning that sustainable urban development is a multilevel governance challenge (van Zeijl-Rozema et al., 2008).

The problems of social proximity were seen inside the organizations at the personal level. One interviewee explained that "those who have known each other for many years do things as they have always done, and they often do not tell me what has happened." There is also a problem because the participating residents are often the same people and new people are not easily available. Building trust could also be jeopardized if there is the potential for political issues to surface. For example, in one city there was an established rule that resident councils are not allowed to be used as places for a political debate.

\section{Impact assessment}


Innovation processes can generate potential outputs and outcomes in social sustainability dimensions. These are critical areas for the social sustainability of local communities, and it is of fundamental importance to assess the potential direct and indirect impact that innovation processes are likely to generate for them (Colantonio and Dixon, 2009). The emphasis must be on the longterm impacts of innovations, because the short-term influence of a product or service often does not reveal the product's real impact on people or society. Innovation could be considered successful in terms of innovations that are perceived to lead to a desirable result in the eyes of the stakeholders. In order to evaluate the impacts (prospective, retrospective or multidirectional) of the desired results, different evaluation methods should be applied. In the context of urban development, innovation should correspond to the preferences of elected politicians, make life easier for public employees and create higher user satisfaction. In real life, however, different stakeholders evaluate innovation outcomes in different ways. It was mentioned that "the effects of developing residential areas always have far-reaching consequences," though the use of assessment methods was inadequate or lacking.

In this state, the current innovation processes could not be considered socially sustainable even though they include some of the elements. Table 2 presents a strategy that proposes which elements in current urban innovation processes should be eliminated, raised, reduced and created in order to make them more socially sustainable innovation processes. 
Table 2. The strategy for socially sustainable innovation processes.

\begin{tabular}{|c|c|}
\hline $\begin{array}{l}\text { Eliminate } \\
\text { Working in bureaucratic silos } \\
\text { Pseudo-participation } \\
\text { The use of bureaucratic language and difficult } \\
\text { concepts with residents } \\
\text { Developing the same urban areas with the same } \\
\text { ideas continuously } \\
\text { The personification of the development } \\
\text { Using development gatherings for political } \\
\text { debate } \\
\text { The attitude that the municipality does } \\
\text { everything }\end{array}$ & $\begin{array}{l}\text { Raise } \\
\text { Involvement and expertise of residents } \\
\text { Implementation of the improvements from } \\
\text { residents } \\
\text { Developers being (physically) regularly present } \\
\text { in the work area (building mutual trust) } \\
\text { Functioning communication (the use of various } \\
\text { channels) } \\
\text { Clear aims for the development } \\
\text { Urban regeneration objectives from the strategy } \\
\text { of the city } \\
\text { The role of the private sector in urban } \\
\text { regeneration } \\
\text { The long-term impacts of innovations } \\
\text { Committed leadership }\end{array}$ \\
\hline $\begin{array}{l}\text { Reduce } \\
\text { Deprived images of the places undergoing an } \\
\text { urban regeneration project } \\
\text { Restraining the development into technical or } \\
\text { institutional management. } \\
\text { Managing challenges from one perspective } \\
\text { (department) although it is connected to many } \\
\text { issues } \\
\text { Adverse resource utilization } \\
\text { The frequent change of developers }\end{array}$ & $\begin{array}{l}\text { Create } \\
\text { Different participation methods for diverse } \\
\text { resident groups } \\
\text { Proactive development methods } \\
\text { Different impact assessment tools } \\
\text { Platforms for exchanging knowledge and } \\
\text { learning from experience } \\
\text { Transparency in decision-making levels } \\
\text { Possibilities for collaboration between } \\
\text { heterogeneous actors } \\
\text { Open network systems } \\
\text { Enabling conditions for voluntary work } \\
\text { More creative and bold solutions }\end{array}$ \\
\hline
\end{tabular}

\section{Conclusion}

The socially sustainable innovation processes are supported by an open and interactive development approach, resident and user-driven involvement, communication, learning and feedback, and impact assessment. However, these elements of the socially sustainable innovation 
process are realized differently. Many processes include resident participation, or at least the value of residents' knowledge and experience is recognized. However, we may also raise the question of whether the objectives of resident participation are properly understood. Do residents participate for the sake of participation, or will the residents' knowledge be exploited in the development? It is acknowledged that urban development needs a more open and interactive development approach, but in practice it still requires organization. Tunnel vision in urban governance may have created situations where urban development issues do not seem to belong to the responsibility of any of the departments. Changing the old and often excessively bureaucratic way of doing things is difficult and slow.

Though the need for impact assessment was acknowledged, it was almost totally lacking in the development. There are various environmental assessment procedures which aim to establish sustainable development in practice through the systematic analysis of policies, programs and projects to eliminate potential negative environmental impacts and enhance positive impacts. In some cases, the assessment of environmental impacts is compulsory. The assessment of the social aspects of urban development plans and projects is still lacking despite the growing array of social sustainability assessment tools.

In addition, the social sustainability debate within urban development focuses mostly on issues relevant to the communities that currently live in or use the urban areas, with little or no regard to proactive approaches. This means that there is a need for more proactive and future-oriented innovation activities in urban contexts. Uotila et al. (2006) stress the need for visionary capability 
in multi-actor innovation processes, meaning the ability to acquire and assimilate future-oriented knowledge.

Socially sustainable innovation calls for new kinds of skills and expertise. The interviews point out that urban developers should be actively involved in different networks. Such connections bring with them the benefit of having an overview of the context and key actors in both the public and private sector, as well as different funding opportunities. There is also a need to facilitate innovation activities and skills and use various methods to enable cooperation among very different stakeholders while understanding their different interests.

The set of skills required for the interaction mentioned above includes communication skills, such as the dissemination of information in the region, and internal communication between the inhabitants, which generates interest in participation. Successful developers do not just build upon knowledge and technical skills. A number of social skills also emerged as key to successful operations; therefore attention should be paid to these abilities. The skills of urban developers come close to those of innovation brokers. According to the innovation literature, the role of brokers includes establishing ties to other disparate or disconnected groups, enhancing communication, learning and other forms of interaction, creating an atmosphere that stimulates knowledge sharing, enabling a fair distribution of the costs and benefits between innovation network members, and anticipating and resolving conflicts between the members (Klerkx and Leeuwis, 2008; Parjanen, 2012). 
The socially sustainable innovation process does not automatically produce socially sustainable innovations or social innovations as a rule. Thus, with a socially sustainable innovation process, these aspects are likely to emerge or a beneficial platform may be established. Hence, social sustainability and social innovations can be achieved in different innovation processes even if the process itself does not meet the requirements of the key elements in the socially sustainable innovation process per se. However, socially sustainable innovation processes have an essential role in building more sustainable communities worldwide. Consequently, this provides highly interesting opportunities for future research related to the skills of developers, assessment frameworks or proactive sustainable development approaches. 


\section{References}

Alam I. 2002. An exploratory investigation of user involvement in new service development. Journal of the Academy of Market Science 30: 250-261. doi.org/10.1177/0092070302303006

Amado M, Santos E, Moura E, Silva V. 2009. Public Participation in Sustainable Urban Planning. International Scholarly and Scientific Research \& Innovation 3: 228-234.

ARA The Housing Finance and Development Centre of Finland. 2013. Development programme for residential areas. http://www.ara.fi/en$\underline{\text { US/Programmes_and_projects/Development_programme_for_residential_areas/Develop }}$ ment_programme_for_residential_ar\%2817358\%29 [March 16, 2017]

Bagheri A, Hjorth P. 2007. Planning for Sustainable Development: a Paradigm Shift Towards a Process-Based Approach. Sustainable Development 15, 83-96. DOI: 10.1002/sd.310

Boons F, Montalvo C, Quist J, Wagner M. 2013. Sustainable innovation, business models and economic performance: an overview. Journal of Cleaner Production 45: 1-8. doi.org/10.1016/j.jclepro.2012.08.013

Boschma R. 2005. Proximity and innovation: A critical assessment. Regional Studies 39: 61-74. doi.org/10.1080/0034340052000320887

Bramley G, Power S. 2009. Urban form and social sustainability: the role of density and housing type. Environment and Planning B: Planning and Design 36: 30-48. doi.org/10.1068/b33129

Brinkmann S, Kvale S. 2014. InterViews: Learning the Craft of Qualitative Research Interviewing. Sage Publications.

Chesbrough H. 2003. Open innovation. The new imperative for creating and profiting from technology. Harvard Business School Press: Boston.

Chesbrough H, Vanhaverbeke W, West J. 2006. Open Innovation: Researching a New Paradigm. Oxford University Press: London.

Chiu R. 2003. Social sustainability, sustainable development and housing development: The experience of Hong Kong. In Housing and social change: East-west perspectives, Forrest R, Lee J (eds). Routledge: USA; 221-239.

Choguill C. 2008. Developing sustainable neighbourhoods. Habitat International 32: 41-48. doi.org/10.1016/j.habitatint.2007.06.007 
Colantonio A, Dixon T. 2009. Measuring Socially Sustainable Urban Regeneration in Europe. Oxford Institute for Sustainable Development (OISD) School of the Built Environment, Oxford Brookes University.

Dempsey N, Bramley G, Power S, Brown C. 2009. The social dimension of sustainable development: defining urban social sustainability. Sustainable Development 19: 289-300. DOI: $10.1002 / \mathrm{sd} .417$

Dessein J, Soini K, Fairclough G, Horlings L. (eds) (2015) Culture in, for and as Sustainable Development. Conclusions from the COST Action IS1007 Investigating Cultural Sustainability. University of Jyväskylä: Finland.

Fortkamp U, Staffas L. 2012. Integration of sustainability aspects in innovation processes. A survey as part of the SPIN project. IVL Swedish Environmental Research Institute Ltd.

Hilgers M. 2013. Embodying neoliberalism: thoughts and responses to critics. Social Anthropology 21: 75-89. DOI: 10.1111/1469-8676.12010

Johannesburg Declaration on Sustainable Development. 2002. http://www.undocuments.net/jburgdec.htm [March 16, 2017]

Klerkx L, Leeuwis C. 2008. Matching demand and supply in the agricultural knowledge infrastructure: Experiences with innovation intermediaries. Food Policy 33: 260-276. doi.org/10.1016/j.foodpol.2007.10.001

Krueger R, Buckinham S. 2012. Towards a 'Consensual' Urban Politics? Creative Planning, Urban Sustainability and Regional Development. International Journal of Urban and Regional Research 36: 486-503. DOI: 10.1111/j.1468-2427.2011.01073.x

Larsen G. 2009. An Inquiry Into the Theoretical Basis of Sustainability: Ten Propositions. In Understanding the Social Dimension of Sustainability, Dillard J, Dujon V, King M, (eds), Routledge: New York; 45-82.

Littig B, Griessler E. 2005. Social sustainability: a catchword between political pragmatism and social theory. International Journal of Sustainable Development 8: 65-79.

Mahdavinejada M, Amini M. 2011. Public participation for sustainable urban planning in Case of Iran. Procedia Engineering 21: 405-413. doi.org/10.1016/j.proeng.2011.11.2032

Mattsson J, Sørensen F. 2015. City renewal as open innovation. Journal of Innovation Economics \& Management 1: 195-215. DOI: 10.3917/jie.016.0195 
Mehdipour A, Rashidi Nia H. 2013. Persian Bazaar and Its Impact on Evolution of Historic Urban Cores - the Case of Isfahan. Macrotheme Review A multidisciplinary journal of global macro trends 2: 12-17.

Mieg H. 2012. Sustainability and Innovation in Urban Development: Concept and Case. Sustainable Development 20: 251-263. DOI: 10.1002/sd.471

Oliveira C, Breda-Vázquez I. 2012. Creativity and Social Innovation: What Can Urban Policies Learn from Sectoral Experiences? International Journal of Urban and Regional Research 36: 522-558. DOI: 10.1111/j.1468-2427.2011.01024.x

Parjanen S. 2012. Creating Possibilities for Collective Creativity. Brokerage Functions in Practice-Based Innovation. Acta Universitatis Lappeenrantaensis 474. Lappeenranta University of Technology.

Peterson N. 2016. Introduction to the special issue on social sustainability: integration, context, and governance. Sustainability: Science, Practice, \& Policy 12: 3-7. doi.org/10.1080/15487733.2016.11908148

Reuber R. 2010. Strengthening Your Literature Review. Family Business Review 23: 105-108. DOI: $10.1177 / 0894486510368259$

Sharifi A, Murayama A. 2013. Changes in the traditional urban form and the social sustainability of contemporary cities: A case study of Iranian cities. Habitat International 38: 126-134. doi.org/10.1016/j.habitatint.2012.05.007

Spangenberg J. 2004. Reconciling sustainability and growth: criteria, indicators, policies. Sustainable Development 12: 74-86. DOI: 10.1002/sd.229

Stren R, Polèse M. 2000. Understanding the new sociocultural dynamics of cities: comparative urban policy in a global context. In The Social Sustainability of Cities: Diversity and the management of change, Polèse M, Stren R (eds). Toronto University Press: Toronto; 338.

Sveiby K-E, Gripenberg P, Segercrantz B, Eriksson A, Aminoff A. 2009. Unintended and Undesirable Consequences of Innovation. Paper presented at XX ISPIM conference The Future of Innovation Vienna June 21-24, 2009.

Uotila T, Harmaakorpi V, Melkas H. 2006. A method for assessing absorptive capacity of a regional innovation system. Fennia 184: 49-58. 
Vallance S, Perkins H, Dixon J. 2011. What is Social Sustainability? A clarification of concepts. Geoforum 42: 342-348. doi.org/10.1016/j.geoforum.2011.01.002

van der Veen M, Korthals Altes W. 2012. Contracts and learning in complex urban projects.

International Journal of Urban and Regional Research 36: 1053-1075.

DOI:10.1111/j.1468-2427.2011.01053.x

van Zeijl-Rozema A, Cörvers R, Kemp R, Martens P. 2008. Governance for sustainable development: a framework. Sustainable Development 16: 410-421. DOI: 10.1002/sd.367 von Hippel E. 2005. Democratizing Innovation. MIT Press: Cambridge, MA.

Wood M. 2002. Resident participation in urban and community renewal Australian Housing and Urban Research Institute. AHURI Final Report No. 23. Australia: UNSW/UWS Research Centre.

Yung E, Chan E, Xu Y. 2011. Sustainable Development and the Rehabilitation of a Historic Urban District - Social Sustainability in the Case of Tianzifang in Shanghai. Sustainable Development 22: 95-112. DOI: 10.1002/sd.534 